International Journal of Biology, Pharmacy and Allied Sciences (IJBPAS) 'A Bridge Betuen Caboratory and QRendor'

WwW.ijbpas.com

\title{
WOMEN RIGHT IN TAMILNADU: A STUDY WITH SPECIAL REFERENCE TO HARASSMENT AND THE FUNCTION OF SHRC
}

\section{BOSE SSC ${ }^{1}$ AND M.DEEPA $M^{2}$}

1: Assistant professor, Department Of Political Science, Cuddalore.

2: Assistant professor, Department Of Political Science, Government Arts College Coimbatore, Coimbatore-641018

\section{"Corresponding Author: DR. S. Subash Chandra Bose}

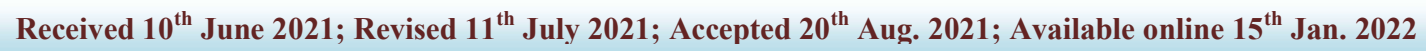

\section{https://doi.org/10.31032/IJBPAS/2022/11.1.1078}

\begin{abstract}
In 1947 there were various struggles and movements in support of women. women in India are deprived of their fundamental right to dignity also, leave alone the question of gender parity.some Issues faced by the women in Tamil Nadu,India like Harassment, dowry, female foeticide, denial of inheritance rights, sale and trafficking of girls, etc. The objective of the paper is to discuss women's harassment in overall Tamilnadu.
\end{abstract}

Keywords: Women's, Rights, Problems, Women Fighter, Harassment, Human Right, Conclusion

\section{INTRODUCTION:}

Many reformers, including Ram Mohan Roy, Ishwar Chandra Vidyasagar, and JyotiraoPhule, fought for women's rights during the British era. Peary Charan Sarkar, a former student of Hindu College in Calcutta and a member of "Young Bengal," founded India's first free school for girls in Barasat, a Calcutta suburb, in 1847. While this may appear to imply that the British made no positive contributions during the Raj, this is not entirely true. Martha Mault née Mead and her daughter Eliza Caldwell née Mault, missionaries' wives, are credited with pioneering the education and training of girls in south India. This practice was initially met with local opposition because it went against tradition. In 1829, Governor-General William Cavendish-Bentinck abolished Sati as a result of Raja Rammohan Roy's efforts. The Widow

\footnotetext{
IJBPAS, January, Special Issue, 2022, 11(1)
} 
Remarriage Act of 1856 was the result of Ishwar Chandra Vidyasagar's crusade for bettering the situation of widows. Pandita Ramabai, for example, was a woman reformer who aided the cause of women.

In response to the Doctrine of Lapse, Kittur Chennamma, queen of the princely state of Kittur in Karnataka, led an armed rebellion against the British. The Queen of Jhansi, Rani Lakshmi Bai, led the Indian Rebellion of 1857 against the British. She is now regarded as a national hero. Another ruler who led the revolt of 1857 was Begum Hazrat Mahal, the co-ruler of Awadh. She retreated to Nepal after refusing to make deals with the British. During this time, the Begums of Bhopal were also notable female rulers. They had received martial arts training. Some of the first Indian women to earn a degree were Chandramukhi Basu, Kadambini Ganguly, and Anandi Gopal Joshi. The first women's delegation, supported by the Indian National Congress, met with the Secretary of State in 1917 to demand women's political rights.

In 1927, the All India Women's Education Conference was held in Pune, and it quickly became a major player in the social change movement. The Child Marriage Restraint Act was passed in 1929, requiring a girl to be fourteen years old before marrying. Mahatma Gandhi, who was a victim of child marriage when he was thirteen years old, later advocated for a ban on child marriages and encouraged young men to marry child widows. Discriminatory, Personal, Physical, Power, Psychological, Online, Retaliation, Sexual, Quid Pro Quo, Third Party, Verbal, Prevention are some of the forms of harassment that women face today.

\section{State Human Right Commission (SHRC):}

The SHRC's responsibilities include a wide range of functions outlined in section 12 of the Act, "all or any" of which, except for those outlined in clause (f) of the section relating to treaties and other international instruments on human rights, which can only be handled by the National Human Rights Commission, are to be performed by this Commission. These functions include investigating complaints of human rights violations or abetment, or negligence in the prevention of such violations by a public servant, suomotu, or on a petition presented to it by a victim or any person on his behalf. Another is to intervene in any proceeding involving any claim of human rights violation before a court with the permission of that court. Under intimation to the State Government, visit any jail or other institution under the State Government's control where persons are detained or lodged for treatment, reformation, or protection to study the living conditions of the inmates and 
make recommendations thereon, review the safeguards provided by or under the constitution of any law currently in force for the protection of human rights and recommend measures for their effective implementation.

Not applicable to State Human Rights Commission, review the factors that inhibit the enjoyment of human rights, including acts of terrorism, and recommend appropriate remedial measures, undertake and promote human rights research, spread human rights literacy among various sections of society, and promote awareness of the safeguards available for the protection of these rights through publications, seminars, and other available means. encourage non-governmental organizations and institutions working in the field of human rights, and perform any other responsibilities it deems necessary for the advancement of human rights.

\section{The Tamil Nadu State Commission For}

\section{Women:}

After that, in 1993, the Tamil Nadu State Commission for Women was established as a statutory authority to deal with incidents of crime against women. The Women Commission has a chairperson and nine members. It analyses specific women's problems and conducts studies on women's topics. The Women Commission is also vested with sufficient powers to protect women's rights and to ensure equality and protection for women against all forms of harassment and problems that women face in their families and communities. The Commission also takes various steps to raise public awareness about women's legislation.

The objectives of the Commission are:-

- To safeguard women and ensure their wellbeing.

- To address the issue of gender inequality.

- Make recommendations to the government on a variety of women's problems.

\section{The Women's Commission's Activities:}

1. The Commission ensures that the provisions and protections granted for women in the Constitution and legislation are followed.

2. Inform the government when various agencies fail to adequately execute protective measures for women.

3. Recommends changes to legal provisions when they fail to provide justice to women.

4. Takes up complaints involving violations of women's rights and follows up with the appropriate authorities. Women can directly contact the Women Commission for redress if they have complaints about violations of their rights or non-implementation of protective measures stipulated by the Indian Constitution.

The State Human Rights Commission (SHRC) has demanded a report from the Tamil Nadu government, inquiring as to whether the 
Tamil Nadu Police had any legal authority to use the 'Friends of Police' movement for official purposes. D. Jayachandran, the acting chair of the SHRC, requested a report from the Home Secretary and the Director-General of Police within four weeks. The Commission also wanted to know if using the 'Friends of Police' movement to carry out the official functions of the Tamil Nadu Police was a violation of human rights and a violation of the Supreme Court of India's ruling in Prof. Nandini Sundar Vs. State of Chhattisgarh.

\section{Constitutional rights available to women in}

\section{India:}

Article 14: Prohibition of discrimination based on religion, race, caste, sex, or place of birth is a fundamental right to equality before the law in India. Art 15(3), on the other hand, permits the state to establish any specific provisions for women and children.

Article 15: Equality of opportunity in areas of public employment or appointment to any state position, and prohibition of sex discrimination.

Article 16: Right of speech and expression, as well as the freedom to conduct any profession, trade, or business.

Article 19: Life and personal liberty are protected.

Article 21: Right to Privacy\& Right to property
Article 300: Political rights for women reservation in, for instance, panchayats.

The Directive Principles of State Policy in India's Constitution provide duties for the state to apply these principles when enacting laws. These principles state that the state shall direct its policies to ensure that citizens, both men and women, have an equal right to an adequate means of livelihood, that men and women receive equal pay, that children receive free and compulsory education, and that the state has a responsibility to improve public health. Whereas fundamental rights are enforceable, in the sense that a victim can seek legal remedy in a court of law, directive principles are just a guiding factor, and their non-observance is not actionable in a court of law.

\section{Women's leader's contribution:}

\section{Issues:}

Subramania Bharati, TiruppurKumaran, Velu Nachiyar, Vanchinathan, Veerapandiya Kattabomman, Dheeran Chinnamalai, and Subramaniya Siva are some of the ladies who have contributed to the rights of women. Anjalai Ammal, there are other women. Supriya Cherian's grandmother, Anjalai Ammal, was a social worker and reformer from Kadalur. Supriya Cherian and her husband were active campaigners during the Rukmini Lakshmipathi, Krishnammal Jagannathan, R.S. Subbalakshmi, 
Ambujadambal, S. Dr. Muthulakshmi Reddy was a prominent leader who fought vehemently against the system.

\section{Sexual harassment issues:}

Women often withhold information about sexual harassment situations for a variety of reasons, including:

Embarrassment and embarrassment about the experience.

Concerns that the issue will be trivialized and ignored.

Anxiety that they would not be believed because there is typically no evidence of the incident.

Fear that the institution will do nothing and the perpetrator will get away with it. Even if the harasser is proven guilty, the fear of being fired or transferred remains. Fear of being subjected to further humiliation as a result of rumors.

Fear of negative consequences and reprisal from the harasser or perhaps the main employer Fear of being accused of 'inviting' or even bringing up the address subject. A notion of conforming to social norms, in which women are encouraged to remain silent and overlook men's "poor behavior."

\section{Physical violence and harassment.}

"The use of physical force against another individual or group that results in bodily, sexual, or psychological harm" or "any attempt at physical injury or attack on a woman, including real physical harm" are useful definitions of physical violence. There is a tendency to emphasize on workplace mass shootings, especially those that result in homicides, as the defining sort of physical violence. Although homicides account for a small minority of occurrences of physical violence in the workplace inTamil Nadu and throughout all states, they are certainly a source of concern for some.It's also worth noting that, in comparison to psychological violence, various forms of physical violence are generally recorded less frequently in the workplace, as detailed further below. Workplace-specific regulations rarely control exclusively physical forms of violence and harassment. They usually use the terms "physical assault" or "attack" without clarifying the meanings.

\section{Psychological violence and harassment :}

The most commonly reported kind of workplace violence and harassment is psychological violence and harassment, which includes verbal and nonverbal abuse, psychological and sexual harassment, bullying, mobbing, and threats. Manipulation of a person's reputation, isolation, withholding information, assigning duties that are incompatible with capabilities, and setting unattainable goals and deadlines are all 
examples of this. In the term "psychological violence and harassment," the adjective "psychological" alludes to the negative consequences such behavior has on the victim's psychological well-being. In France, the term "moral harassment" is defined as "repetitive acts with the goal or effect of degrading the working circumstances of employees in a manner likely to impair their right to dignity, to alter their physical or mental health, or to jeopardize their professional future" under the Labour Code. Psychological violence and harassment can be defined in national laws in two ways: broadly, with legislation protecting all workers under the terms "mobbing," "bullying," "harassment," and "violence," or narrowly, with legislation only protecting a person who is harassed based on a specific real or perceived difference such as race, color, sex, religion, political opinion, national extraction or social origin, age, disability, sexual orientation or gender. The terms "mobbing" and "bullying", and sometimes "harassment", have come to be used interchangeably in some countries, regardless of who initiates these acts.

- Verbal Harassment. issues :

A negative statement uttered to or about the victim is defined as verbal abuse, as does censoring any reaction and thereby labeling the target as non-existent. The relationship may be verbally abused if the offender does not apologize and withdraw the abuse statement right away. Withholding, countering, and discounting are all terms used to describe the act of withholding, countering, and Verbal assault disguised as a joke, Blocking and diverting, accusing and blaming, judging and condemning, trivializing are all examples of blocking and diverting. Verbal abuse includes undermining, threatening, ordering, denial, abusive fury, and so on. Section 294 of the Indian Penal Code outlines the penalties for obscene acts or words in public. In Tamilnadu strictly followed law and order against Verbal Harassment issues for women.

\section{Harassment in TamilNadu:}

An Act prohibiting women from being harassed in any place in the state of Tamil Nadu. In the Forty-ninth year of the Republic of India, the Legislative Assembly of the State of Tamil Nadu enacts the following: -

1. (1) This Act is known as the Tamil Nadu Prohibition of Female Harassment Act, 1998.

(2) It shall be assumed to have entered into force on July 30, 1998.

2. Defined terms. - (a) Harassment means any indecent action or acts by a man that causes or is likely to cause intimidation, fear, shame, or embarrassment, including causing pain or 
nuisance, assault, or use of force, unless the context dictates otherwise.

(b) "Public service vehicle" shall have the same meaning as defined in clause (35) of section 2 of the Motor Vehicles Act, 1988 (Central Act 59 of 1988);

(c) words and expressions used but not defined in this Act shall have the meanings assigned to them in the Indian Penal Code, 1860 (Central Act XLV of 1860).

3. Harassment of women is illegal at all times and in all places.

4.Sanctions for sexual harassment of women:

- Anyone who harasses a woman in or near an educational institution, temple or another place of worship, bus stop, road, railway station, cinema theatre, park, beach, festival, public service vehicle or vessel, or any other place is punishable by imprisonment for up to three years and a fine of not less than ten thousand rupees.

4A.When a woman's death is caused by bodily injury or occurs outside of normal circumstances, and it can be shown that she was harassed shortly before her death or that an offense under section 294, 354, or 509 of the Indian Penal Code (Central Act XLV of 1860) was committed in her name, such death is referred to as harassment death. Not withstanding anything in section 4, whoever causes death by harassment, and if the act by which the death is caused,

(i) is done to cause death or of causing such bodily injury as is likely to cause death, shall be punished with imprisonment of either description for a term which may extend to imprisonment for life and with fine which shall not be less than fifty thousand rupees;

(ii) is done with the knowledge that it is likely to cause death but without any intention to cause death or such bodily injury as is likely to cause death, shall be punished with imprisonment of either description for a term which may extend to ten years and with fine which shall not be less than fifty thousand rupees;

(iii) is rash or negligent, shall be punished with imprisonment of either description for a term which may extend to ten years and with fine which shall not be less than twenty-five thousand rupees.]

4B.Harassment suicide (1) If any woman commits suicide and it is shown that soon before her death, she was subjected to harassment by any person or that in respect of her an offense under section 294, 354 or 509 of the Indian Penal Code (Central Act XLV of 1860) was committed, such suicide shall be called the harassment suicide and such person shall be deemed to have abetted the suicide.

(2) Notwithstanding anything contained in section 4, whoever abets harassment suicide shall be punished with imprisonment of either 
description for a term which may extend to ten years and with a fine which shall not be less than fifty thousand rupees.

4C.Presumption as to harassment death and abetment of harassment suicide: When the question is whether any person had caused harassment death or abetted harassment suicide of a woman, the court shall, unless the contrary is proved, presume that such person had caused the harassment death or abetted the harassment suicide, as the case may be, when it is shown that before her death, such woman had been subjected to harassment or, in respect of her an offense was committed under section 294, 354 or 509 of Indian Penal Code (Central Act XLV of 1860) and bodily injury was caused in furtherance of such harassment or commission of the said offense by or at the instance of that person and it resulted in death or suicide, as the case may be, of that woman.]

\section{Responsibility of management of any} precinct. - (1) Any person who is incharge of educational institution, temple or other places of worship, cinema theater or any other precinct shall,-

(a) take such steps as he may deem fit to prevent within the precinct;

(b) on a complaint made by an aggrieved person, give information to the police about the harassment of women.

(2) Any person who fails to take action under sub-section (1) shall be liable to a fine which may extend to two thousand rupees.

\section{Duty of crew in public service vehicles. -} the crew of a public service vehicle or vessel shall take such steps as they may deem fit to prevent harassment of women in the vehicle or vessel(2) Any crew who fails to take steps under subsection (1) shall be liable to fine which may extend to one thousand rupees.

7. Deemed abetment. -where any vehicle or vessel is used in the commission of any offense punishable under section $4,4-\mathrm{A}$ or $4-\mathrm{B}$, The vehicle or vessel specified in sub-section (1) shall be confiscated unless the owner of such vehicle proves that suchwas used in committingwithout his knowledge.

7A.Order to pay compensation The court may, when awarding a sentence under section 4, 4-A or $4-\mathrm{B}$, order the accused to pay, by way of compensation, such amount as may be specified in the order, to the person who has suffered any loss or injury or disability or mental agony by reason of the act for which the accused person has been so sentenced or to her legal heir.]

\section{Operation of other laws not affected. -}

The provisions of this Act shall be in addition to, and not in derogation of, any other law for the time being in force.

9. Power to make rules. - (1) The State Government may make rules for carrying out 
the purposes of this Act.

(2) all rules made under this Act shall be published in the Tamil Nadu Government Gazette and unless they are expressed to come into force on a particular day shall come into force on the day on which they are so published.

(3) Every rule made under this Act shall, as soon as possible after it is made, be placed on the table of the legislative Assembly, and if, before the expiry of the session in which it is so placed or the next session, the Assembly makes any modification in any such rule, or the Assembly decides that the rule should not be made, the rule shall thereafter have effect only in such modified form or be of no effect, as the case may be, so, however, that any such modification or annulment shall be without prejudice to the validity of anything previously done under that rule.

10. Repeal and Saving. - (1) The Tamil Nadu Prohibition of Eve-teasing ordinance, 1998 (Tamil Nadu Ordinance 4 of 1998) is hereby repealed.

(2) Notwithstanding such repeal, anything done or any action taken under the Ordinance shall be deemed to have been done or taken under this Act.

\section{CONCLUSION:}

Despite advances in science and culture, women's rights violations and harassment continue to be an issue. Tamilnadu's government has been enforcing a lot of resolutions and Lawson issues against women with zeal. Women's rights are also being protected by the state human rights commission, which is becoming increasingly involved and contributing. When women expand their lifestyles while also dealing with harassment difficulties, it is a win-win situation.

\section{REFERENCES:}

[1] Shahida Lateef, Wlaither the Indian women's movement in Economic and Political weekly, Bobay, Vol.12, No:47, 1977, P.1948.

[2] Geraldine forbes, caged Tigers; First wave feminists in India; in women ${ }^{\text {ee }}$ studies International forum, Vol.5, No:6, 1982-PP-525-536.

[3] Vijaya Agnew, Elite Women in Indian Politics, Shakti Books, New Delhi. 1979, P104.

[4] Suruchi Thapar - Bj or kest, women in the Indian National movement; sage publication, New Delhi 2006. P.56-57.

[5] Murdock George, social, mamillian, New York -194, P.45.

[6] T.Stallin Gunasekaran, Viduthalai Velviyil Tamilzhagam, (Tamil) Vol. Erode. 2000; PP-154-175. 7. Kudiarasus, 22 August, 1926. 
[7] The Hindu, Chennai -24, April 2002

[8] Kudi Arasu; 26 April, 1931.

[9] S. Rajendran, Tamil Kavithaiyel Dravida Iyakkatin Takkam, Madras.

[10] Sivagamiparamasivam, Human Rights and periyar E.V.R. in Proceedings volume of XIX Annual session of south India, History congress, Chennai - 1999- P.223.

[11] Remembering E.V.R. maniammai, Themoder Rationalist, Chennai March - 1999-P.3.

[12] R.K. Warasimham, Human Rights and Social Justice, Electronic Books new Delhi - 1999 - P.2.

[13] Viduthalai - May -1970. The International journal of analytical and experimental modal analysis Volume XII, Issue II, February/2020 ISSN NO: 0886-9367 Page No:2637

[14] Aftab Alam, Human Rights in India Issues and challenges, Raj Publications, New Delhi - 2000PP-69-70.

[15] Gomathi Sankar, Tamizhka Marumalerchi (Tamil) Tenkasi 1996; PP.72-73. 17. Viduthalai -3 October 1972.

[16] Surbhisinha, Srikanthory, Woman and Human Rights. Alfa Publication, Delhi, 2012- P.223.
[17] Kudi Arasu 26, October -1930 20. P.M. Bakshi, the constitution of India. Universal Law Publishing, New Delhi-1993, P170. 21. Viduthalai 25, January, 1960.

[18] Rao, Mamta (2008). Law relating to women and children (3rd ed.). Lucknow: Eastern Book Co. ISBN $9788170121329 . . . . w o m e$ $\mathrm{n}$ and the protection provided under various criminal, personal and labour laws in India.

[19] Nelasco, Shobana (2010). Status of women in India. New Delhi: Deep \& Deep

Publications.

p. 11. ISBN 9788184502466.

[20] Chowdhury, Kavita (16 June 2011). "India is fourth most dangerous place in the world for women: Poll". India Today. New Delhi: Living Media. Retrieved 13 March 2014.

[21] Team FI (13 June 2012). "India ranked worst G20 country for women". feministsindia.com.

FeministsIndia.

[22] IBN Live. Archived from the original on 6 December 2013.Retrieved 9 October 2013.

[23] Women Cabinet Ministers in India" 1 July 2014. 
[24] C.M. Thakar, S.S. Parkhe, A. Jain etal., 3d Printing: Basic principles and applications, Materials Today: Proceedings, https://doi.org/10.1016 /j.matpr.2021.06.272

[25] Khan, R. M. I., Kumar, T., Supriyatno, T., \& Nukapangu, V. (2021). The Phenomenon of ArabicEnglish Translation of Foreign Language Classes During The Pandemic. IjazArabi Journal of Arabic Learning, 4(3). https://doi.org/10.18860/ijazarabi.v4

\section{$\underline{i 3.13597}$}

[26] Sajja, G., Mustafa, M., Phasinam, K., Kaliyaperumal, K., Ventayen, R., \&amp; Kassanuk, T. (2021). Towards Application of Machine Learning in Classification and Prediction of Heart Disease. 2021 Second International Conference On Electronics And Sustainable Communication Systems (ICESC). https://doi.org/10.1109/icesc51422.2 $\underline{021.9532940}$

[27] Veluri, R., Patra, I., Naved, M., Prasad, V., Arcinas, M., Beram, S., \&amp; Raghuvanshi, A. (2021). Learning analytics using deep learning techniques for efficiently managing educational institutes. Materials

Today:

Proceedings.

https://doi.org/10.1016/j.matpr.2021.11.4

$\underline{16}$ 